TYS6257?

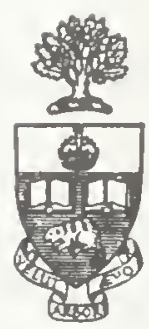

Library

of the

University of Toronto 


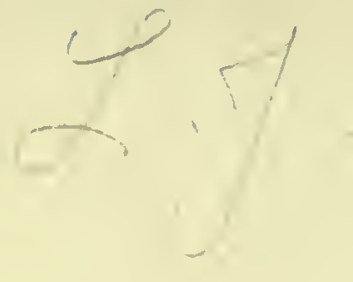

Frist $420+1 \%, \quad 1857$

5 Echared Neusman 
Digitized by the Internet Archive in 2018 with funding from University of Toronto 
THE INSECT HUNTERS. 
London :

Printed by E. Newman, 9, Devonshire St., Bishopsgate. 


\section{THE}

\section{INSECT HUNTERS;}

or,

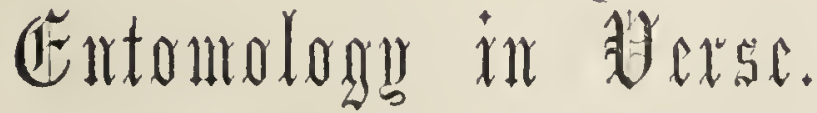

* * * Ballarts that * * *

Speak in tones so plain and childlike, Scarcely can the ear distinguish

Whether they are sung or spoken.

LONGFELOW.

\section{LONDON :}

EDWARD NEWMAN, 9, DEVONSHIRE STREET, BISHOPSGATE.

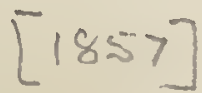


Just as the butterfly, child of an hour,

Flutters about in the light of the sun, Wandering wayward from flower to flower, Sipping the honey from all, one by one;

So does the fanciful verse I've created

Love 'mongst the experts in Science to roam, Drinking their wisdom without being sated, Bringing the sweets of their intellect home.

BELL. 


\title{
LAURA ADA DOUGLAS
}

\author{
PUDS 『R⿴囗十區區
}

Affectionatedely âdrscriber. 



\section{O N T E N T.}

\section{ENTOMOLOGY IN VERSE.}

INTRODUCTION • • •

The Four Stages. Egg, Larva, Pupa, Imago - . 6

inetamorphosis. Lepidoptera, Diptera, Hymenoptera,

Coleoptera, Stegoptera, Neuroptera, Orthoptera and

Hemiptera . • • • • • . . . 9

Tribes of the Scale Wings, or Lepidoptera. The

Butterflies and Moths . • . . . . 14

Tribes of the two Wings, or Diptera. The Gnats and Flies • • • • • • • • • • 23

Tribes of the Clear Wings, or Hyienoptera. The Sawflies, Gallflies, Ichneumons, Bees, Wasps, Sandwasps and Ants . . . . . . . . 33

Tribes of the Case Wings, or Coleoptera. The Beetles . . . . . . . . . 43

Tribes of the Roof Wings, or Stegoptera. The Ant Lions, Lace Wings, Scorpionflies, Snakeflies and Caddisflies . • . . . . . . . 50

Tribes of the Net Wings, or Neuroptera. The Dayflies, Dragonflies, Demoiselles, White Ants and Stoneflies . . . . . . . . . 57 
Page

Trmes of the Straight Wings, or Orthoptera. The Earwigs, Cockroaches, Crickets, Locusts and Grasshoppers • • • • • • • • • 68 Tribes of the Hadf Wings, on Hemptera. The

Plant Bugs, Water Boatmen, Water Scorpions, Froghoppers and Plantlice . . . . . . 72 VALEDICTION • • • • • • • .

\section{ENTOMOLOGICAL SAPPHICS.}

I. The Butterfy • • • . . . . 83 II. The Firefly . . . . . . . . 84 III. The CICADA • . . . • . • 85 


\section{Entomologn in the}

\section{INTRODUCTION.}

Should you ask me, whence these lessous, With their deep and wholesome teaching?

Whence these numerous descriptions, With their music, with their magic, With their breathings of the forest, With their gleams of summer sunshine, With their dew drops bright and sparkling, With their scents and sounds delicious, Scents of haymaking in meadows, Sounds of happy creatures humming, With their frequent repetitions, To the youthful mind so needful? I should answer, I should tell you, "From the wild wood and the forest, From the corn field and the meadow, From the park and from its palings, 
From the river gently flowing, From the land of the Edusas, From the land of the Sybillas, From the blue flower of the lucerne, From the white flower of the bramble, From the thistle and the teazle, Where the brilliant Peacock, Io, Loves to sip the liquid honey, . Lores to spread his painted pinions:

I repeat them as I heard them ess / From the truthfin lips of Douglas, of Friend, Philosopher and Mentór."

Should you ask me where the Douglas Found these lessons and descriptions, I should answer, I should tell you, "In the wild bees' mossy dwelling, In the crevices of elm trees, In the depths of wood decaying, In the foliage of the hedgerow, In the deep and hollow sand pit, All the insects sang them to him: In the oak woods, in the fen lands, In the melancholy marshes, The Copper, Hippothoë, sang them, And the Swallowtail, Machaon, And the Emperor, the Iris, Clad in robes of 'Tyrian purple." And if further you should asli me, 
Saying, "Who, then, is this Douglas? Who this great and déarned Douglas?

Tell us all about this Douglas,"

I should answer your inquiries

Straightway in the words which follow.

"Very near the Blackheath Station,

Station of the North Kent Railway, In a lonely place called Kingswood, Dwells the wise and le farned Douglas; There he wrote the 'World of Insects ;' And before the honoured dwelling Stands a single graceful birch tree, And a somewhat stunted willow. Deep within that honoured dwelling Live the Douglas and his children, Wondrous Alice, silkhaired Laura, Sober Polly, Pauline Zeller, Fattest Harry, Henry Stainton, Dohrn, the namesake of the gifted, And a new and perfect baby.

It was this same Douglas taught me."

Should you ask me why to Laura

I address such stores of learning, I should answer, I should tell you, "This is science which her spirit Takes a keen delight in learning, And I feel an honest pleasure In returning to the daughter 
What I borrowed from the father.

Hear, again, another reason:

Haply other sons and daughters,

Unknown to me, unknown to Laura,

May peruse these lines more gladly

When they see that $I$ address them

To a young and playful maiden, And, perusing them more gladly,

May the more readily acquire

Some slight knowledge of their meaning."

Ye who love the face of Nature,

In the storm or in the sunshine,

In the deep shade of the forest,

On the high and naked mountain;

Ye who trace the Malier's finger

In this world of his creation,

And look through this bright creation,

Through these Ios and Edusas,

These Sybillas and Machaons,

Through the hosts of minute creatures,

Peopling every blade and blossom,

Up aloft to Him who made them;

$\left(\begin{array}{l}\text { Ye whose hearts are fresh and simple, } \\ \text { And have faith in God and Nature, }\end{array}\right)$

Who believe with all your spirit

In benevolence etermal,

Inexhaustible and perfect;

Ye who sometimes in your rambles 
Through the green lanes of the country,

Where the Clematis and brier

Intertwine their arms in wedlock,

Pause to drink a draught of pleasure,

Far apart from all that's worldly ;

You I ask to read this Poem,

Read this short and simple Poem;

Ponder o'er its peaceful teaching;

Read, and then, if thus it please you,

Take the lines that I have stolen,

The sweet lines that I have stolen,

From the song of 'Hiawatha,'

And return them, and restore them,

To their great and gifted author. 


\section{THE FOUR. STAGES.}

Take thy hat, my little Laura, Fix it by the loop elastic; Let us go to Haddo Villas, Passing by the church and churchyard, Now so bright with shortlived flowers, Apt mementos of the buried;

Passing, hand in hand together, Passing, old and young together, Gravely walling, gaily tripping, Through the shady lane of lovers, Where the railtrain rattles under, And so on to Haddo Villas. I will give thee as we linger, Here and there upon our journey, A first lesson in the science That we mean to learn together;

For all teaching is instructive To the teacher and the learner ;

Entomology, the science That we mean to learn together;

Entomology, the science 
That will show us, that will tell us, All about the world of insects.

Flying insects have four stages, States or stages as you like it, In their very brief existence; And in what I teach hereafter, In our country walks together, I shall mention very often Larva, pupa and imago, The more common of these stages. Learn, then, first, the names we call them. First, the EGG. Upon these palings See this web so dingy looking, And these round things glued upon it, Sticking side by side together, Very much like pins' heads flattened: These are eggs, and their hereafter Will be different as Laura's. Look again; see where the privet Overtops the lofty palings;

See this giant caterpillar, Smooth and of a bright green colour, Marked along each side with stripings Of a most delicious purple: This, my pupil, is a Larva, Larva, grub or caterpillar. Look again upon the palings; See another web, and in it 
Is a yellow, powdered, eggshaped Something, which we'll gently open, And within, dark brown and lumplike Is the chrysalis or Pupa.

Once more look upon the palings; See this butterfly with white wings Standing straight up from his body, And so closely pressed together, Back to back, they seem united: This, my child, is an Irrago, Perfect insect or imago.

These are states of different insects; The Vapourer is in the egg state; The caterpillar, Sphinx Ligustri ; The pupa is the common Lacquey, Neustria or common Lacquey ;

The perfect butterfly, imago, We may call Pieris. Rapæ.

Once again repeat the stages:

First of all we see the egg state;

Then the caterpillar, larva;

Then the chrysalis or pupa;

Last of all is the imago,

Perfect insect or imago.

These are easy to remember.

Now trot on to Haddo Villas, There to see the gentle Edith, And the pretty little Ada, 
And the very little baby, And the grave and noble Percy, Haply to be crowned with mitre, Archepiscopal hereafter. Ah! how little can'st thou fathom A fond father's high aspirings.

\section{II.}

\section{METAMORPHOSIS.}

Would that I could skip this lesson, Laura; well I know 'tis tiresome For a child like thee to listen To a tale in learned language That were better told in English, If I linew but how to do it.

But the words that I must teach thee Have as yet no good translations, No equivalents in English, Or I'd very gladly use them. I have told thee of the egr state, 
Larva, pupa and imago,

That are common to all insects;

Let us now regard the pupa

In its various forms and phases.

Sometimes it is hard and lumplike, Wrapped in coating tough and leathery;

It moves not, and of course it eats not; 'Tis to all appearance lifeless :

Such a pupa is amorphous, Shapeless, and we call Amorpha All the insects with such pupæ. Now, if these amorphous pupæ

Come to butterflies and night moths, With four wings so broad and ample, Thiclily covered up and hidden, With small scales of different colours, Scales that seem almost like powder, When rubbed off upon the finger, Then we call the insects Scale Wings, Lepidoptera or Scale Wings; But if they have two wings only, And those two are quite transparent, Without any scales or clothing, Then we call such insects Two Wings, Diptera, or having two wings.

Let us take another pupa; And this also moves not, feeds not, But its limbs are quite apparent, 
Legs and wings and head and feeler's,

All enclosed in separate cases,

Fitting close, transparent cases :

Then we call them necromorphous ;

They are living insects deathlike,

Or in Latin Necromorpha.

When the necromorphous pupa

Comes to a fourwinged imago,

All the wings quite clear and naked, And all four well formed for flying, And the tail armed with a weapon, Sometimes stinging, always stinglike, Hrmenoptera we call them, Hymenoptera or Clear Wings ; But if they have two wings only, Covered with two hard wing cases, Coleoptera we call them, Coleoptera or Case Wings, Coleoptera or beetles. Then, again, if Necromorpha Have four wings alike and netlike, Oftentimes a little hairy, Meeting in the middle, rooflike, And a tail that's always stingless, Without any piercing weapon, Then Stegoptera we call them, Class Stegoptera, or Roof Wings. Lastly, come some other pupæ, 
Longlegged, active, running, leaping, Doing everything but flying;

Eating, too, and very greedy, Gnawing, killing, tearing, sucking ; Shaped exactly like the larvæ, And much like the perfect insect, Only that the wings are wanting:

These are isomorphous pupæ, And the insects IsOMORPHA.

When the isomorphous pupa Comes to a fourwinged imago, All the wings alike and netlike, And the mouth is formed for biting, With strong bony jaws for biting, Then Neuropters we call them, Class Neuroptera, or Net Wings. When the wings are straight and rooflike, And the fore wings tough and leathery, And the hind wings clear, and folded Lengthwise neatly underneath them, And the mouth is formed for biting, With strong bony jaws for biting, Then OrтhортеRA we call them, Class Orthoptera, or Straight Wings.

One more class of Isomorpha, One more class, and then the cherries ; Alice and the rest must share them. When an isomorphous pupa 
Comes to a fourwinged imago, And the wings are folded over At the very tips and crossing, And the bottom half is leathery, And the outer half transparent, Or when all the wings are gauzy, Quite alike and meeting rooflike, Then Hemiptera we call them, Class Hemiptera, or Half Wings. Now, look we to the mouth, my Laura: These Hemiptera, or Half Wings, Differ much in their wing fashion, But the mouth is never varied, Straight and tubular for sucking, Without any jaws for biting. Here will end our second lesson, After once the names repeating: Lepidoptera, or Scale Wings; Then come Diptera, or Two Wings ; f in Hymenoptera, or Clear Wings, Recollect that these are stinging; Coleoptera, or Case Wings; in sen Then Stegoptera, or Roof Wings ; Then Neuroptera, or Net Wings; Then Orthoptera, or Straight Wings ; And Hemiptera, or Half Wings. 


\section{TRIBES OF THE SCALE WINGS.}

Let us take a stroll, my Laura, Down Farm Lane and to the sedge pond, Where thy father often fishes

For the pretty water beetles, Grapii and branchiatus, Hubneri and marginalis, Agilis and punctulatus, Ater, Sturmii and fuscus, Pretty Colymbetes fuscus, That my Laura once caught flying. Thence we'll turn to rural Burnt Ash. Haply we may meet with Stainton, With his ardent class around him. As we walk I'll try and teach thee Something more about the Scale Wings. Lepidoptera, or Scale Wings, Are the butterflies and night moths, And we know them by the scaled wings, And the mouth, so like a watch spring, Coiled up underneath their faces ; 
'Tis a tube through which the insect Sucks the honey from the flowers. Sit down on this bridge a minute, Looking on the tiny river As it runs among the sedges, And then I will try to tell thee All I know about the Scale Wings, How to group them into orders.

First, the Papilionina, Take the precedence for beauty. / Butterflies we always call them, And it is not hard to know them : First, they always fly in sunshine ; Then they have these knobbed antennæ, Coming forwards from the forehead; These are sometimes called the feeler's, And some think them ears for hearing, But we know they are antennæ, And were made for some wise purpose; What that purpose is we know not. All their wings are very ample, And the hind wings gaily coloured, Gaily coloured like the fore wings, Never hidden by the fore wings, Never folded up beneath them. When these insects rest at nighttime, Or would hide from passing showers, Then their wings are all erected, 
Meeting up above their bodies.

Next to these, the large Sphingina

Have antennæ pointed outwards,

Rather thickest in the middle,

Notched along the side, or sawlilie;

And their tube for honeysucking

Is both large and very lengthened;

The fore wings are long and pointed,

And the hind wings shorter, smaller,

Often much more gaily coloured, Always hidden by the fore wings.

When the noble Sphinx is resting

On the tree trunks in the day time,

All the four wings then meet, rooflike.

They have large and pointed bodies,

Often banded with bright colours.

Sphinges fly in early evening,

Sipping sweets from honeysuckles

And all honeyyielding flowers,

While they hang, in air suspended,

On their quivering wings suspended.

Thirdly, the soft Bombycina, With antennæ very various,

Mostly short and fringed, or comblike,

With no tube for honeysucking;

Fore wings very broad and rounded;

Hind wings also broad and ample, Folding lengthwise underneath them, 
And much larger than the hind wings Of the Hawk Moths or Sphingina.

The male Bombycina often Fly about in open daylight, Often also in the night time, But not seeking honeyed flowers, Only looking after females, Which are always slow and sluggish, Heary bodied, often wingless.

Next them come the Nocturixa, Dull and dingy in their colours, With antennæ mostly threadlike, Thin and tapering to the summit, But sometimes they are serrated, Slightly serrated or sawlike; They have tubes for sucking flowers, And are very fond of sucking, As we often see, my Laura, When we spread the moistened sugar, Or the sweet and sticky treacle, On the tree trunks to attract them; Wings of moderate dimensions, When the insect rests, deflected Or else folded round the body ; Fore wings hiding all the hind wings, Which are slightly folded lengthwise, And in hue have small resemblance To the colour of the fore wings, 
Sometimes paler, sometimes darker, Often gloriously coloured, As in these superb Triphænæ;

In the Nonpareil, Fraxini;

Crimson Underwing, promissa ; Or the willowfeeding nupta, Common Underwing or nupta, Very beautiful, but common: All these brilliant wings are hidden By the sobercoloured fore wings When the moth by day is resting On the tree trunks or on palings. Next them the Pyralidina, Very like the Noctuina, But more slender and more graceful, Their antennæ very threadlike, All their bodies smooth and slender; All their wings are rather larger, More triangular in outline Than in normal Noctuina, And the insect seems more flattened When it rests upon the palings. Their fore legs are rather longer Than the middle or the hind legs, But, my child, it is not easy 'To decide between these orders; Still the eye, when fully practised, Sees the difference between them. 
Next, the light Geometrina, Truly butterflies of night time, Are distinguished by their larvæ, Called Geometers or Loopers;

But you know we camnot always Find the larvæ to examine, Though we see the perfect insect. Their anteunæ, always tapering, Are not often very threadlike, But are sometimes fringed or comblike. Mark their very slender bodies;

Mark their wings, so very ample;

Mark especially the hind wings When these pretty moths are resting

On a tree, or wall, or palings : You will plainly see the hind wings Are not covered by the fore wings, Never folded up beneath them, And their colours much resemble All the colours of the fore wings; And they run, when you disturb them, With the wings all four erected. On the palings, on the tree trunks, On the leaves in every hedgerow, Settling everywhere, in summer, Are the Bell Moths, Tortricina, Pretty Bell Moths, Tortricina; Their antenmæ rery slender, 
Always simple quite, and threadlike; Fore wings, when the moth is resting, Always bellshaped in their outline; The hind wings are always folded Neatly undemeath the fore wings, Never coloured like the fore wings.

Now a word about the larva, To the gardener mischievous. See the rose leares spun together, And, when opened very gently, Watch the larva wriggling backwards, Through some aperture unnoticed, And then hang in air suspended, By a thread of its own spinning: Everywhere you find such larvæ, Spimning up the leaves together, In the garden, in the wild wood, In the hedgerow, from the oak trees, All throughout the days of summer, You may see them gently swinging, Jyy a silken cable swinging, In the bright and breezy sunshine, Swinging as for recreation.

'Tiny Scale Wings, Trxerna, Lilie in nothing but their smallness, Minims of the class of Scale Wings. I am well aware, my Laura, Smallness is a most uncertain 
And comparative distinction,

Hence it is ignored in Science.

Haply, in the distant future,

Some great teacher like thy father

May supply us with the knowledge

How to separate these minims

From the other larger Scale Wings,

And to group them after Nature.

Very various are the larvæ;

Some are smooth and others hairy,

Some are stout and others slender,

Mostly they are sobercoloured,

But a few are gaily tinted.

In all places you may find them,

In the house our old clothes eating,

In the gardens in the apples,

In the woods inside the acorns,

In the hedges, in the meadows,

Where they feed on every green thing,

Nibbling at the leaves and flowers,

Sometimes turning down a corner

Of the young leaves, and so making:

For themselves a tentlike dwelling,

Where each feeds at will securely.

Some make cases which they live in,

Locomotive habitations,

Of all kinds of forms fantastic,

Houses which they carry snaillike. 
All the wings are very narrow, All have long and silken fringes; Hind wings hidden by the fore wings, And of dull and sober colours ; Fore wings variously coloured, Often of a snowy whiteness, Often most obscure and dingy, Some magnificently coloured With the most refulgent splendour, (Splendour as of hues metallic, Living glories evanescent, Purest silver, molten copper. Inexhaustible invention Of the beautiful and charming Is displayed in Tineina! Then, if God so clothe these atoms For a day's or weel's existence, Think, my Laura, how surpassing, How exhaustless is his power!

Is not their history a lesson, Teaching how the God of Nature Cares for his minutest beings, And insures their preservation Through unnumbered generations?

Lastly, the Pterophorina

Have the fore wings and the hind wings Cut in fingerlike divisions ; All the wings are straight porrected, 
At right angles with the body.

These fantasticlooking creatures

Scarcely seem to class with Scale Wings,

But their structure, so abnormal,

Serves to indicate the sequence

Of the Tipulæ or Craneflies,

Which we must ere long consider.

This discourse on Scale Wings ended,

I will pick these purple vetches,

Purple vetches, Vicia cracca,

And I'll twine them in a chaplet,

And the Queen of Scale Wings crown thee.

IV.

\section{TRIBES OF THE TWO WINGS.}

Laura, let us go to Plumstead, By the well known North Kent Railway, Starting from the Blackheath Station, Passing through the Charlton tunnel, Through that damp and darksome tunnel, By the saudy pits at Charlton, 
Through the warlike town of Woolwich; And, alighting then at Plumstead, Let us sweep the grass and heather, Let us search the autumn flowers, For the flies, the trowinged insects. In this large tin case, containing A fèw slips of blotting paper, And a little mass of wadding, Slightly damped with benzine collas, Stupefying fumes exhaling; In this case we will imprison All the twowinged flies we capture. Laura, in our search for knowledge We must kill these pretty insects Now arid then, though very seldom, Just to learn their curious structure More minutely, more completely. When I take the lives of insects Sometimes, in the cause of Science, I employ bruised leaves of laurel, Chloroform or benzine collas, Because these cause stupefaction, That precludes all chance of suffering. Let us constantly remember That they love their lives as we do, That they love to dance in sunshine, Love the balmy air of summer; Often, of a summer's evening, 
By their multitudes creating

Quite an atmosphere of insects, Atmosphere of winged atoms.

Olh, how sweet to sit at sunset On some gate among the cornfields, And to watch the busy millions As they seem to rise towards heaven!

Insects love to bask on green leaves, Or to sip the sweets of flowers, Or to chase their gay companions ; Love, in fact, to seek enjoyment ; Spend their short, short life in pleasure, Just as you, my child, or I would. Let us always, then, remember Never wantonly to kill them, 'Though we know not if they suffer. For my part, I own I love them; And far rather would I see them In their happiness while living, Than I'd have the best collection Of their dried and wasted bodies. Now I'll tell thee of the Tro Wings, How to know them, how divide them Into Nature's tribes or orders.

First, the Craneflies, Tipulina, Daddylonglegs, Tipulina; With a head so long and narrow; Thorax thick, and body slender, 
Never nipped in at the middle;

Legs beyond all reason lengthy;

Flight both weak and very flagging.

Larvæ fat and ugly maggots,

Living in the earth, and feeding

On the roots of plants and herbage,

Also on decaying timber.

Pupa without any shellcase,

Breathing through two horns porrected.

Next, the true Gnats so bloodthirsty,

Gnats or Midges, Culicina,

Musquitoes or Culicina:

Males with feathery antennæ,

Females with bloodsucking rostrum;

Both have heads of small dimensions;

Rather long and slender bodies,

Not nipped in or slenderwaisted;

Legs are long and very slender.

In this country some few species

Of these Midges or Musquitoes

Seek our faces in the night time;

With a gentle hum approaching,

And an aperture creating

With their sharply pointed lancets,

Thence imbibe the purple current,

Causing us but slight annoyance;

But in many other countries

Swarms of hungry Culicina 
Seize upon the thinskinned stranger, Banish sleep and drive to madness. Oft we see these dire bloodsuckers Walk the rippling waves in safety In the genial days of summer, Lay their eggs in boatshaped masses On the surface of the water, There to float till warmth and moisture Vivify the sealedup larvæ. Then begins a life aquatic, Always now submerged in water, Mostly swimming near the surface, And when frightened diving under, Writhing briskly to the bottom; But, the threatened danger over, Gently rising, by their lightness, To the surface of the water, Where they always float tail upwards, Because in that droll position They can breathe air without moving. When these larvæ change to pupæ They reverse this strange position, Floating with the thorax upwards, And this for the selfsame reason, Because now their breathing organs, Seated in the rounded thorax, Are thus aptly brought in contact With the atmosphere for breathing; 
But the creature is as active In the pupa as the larva, Diving just as quick, when frightened, Diving deeper in the water, Many summersaults performing, In its hasty progress downwards, Till it finds itself in safety, And then gently floating upwards, By its lightness, to the surface. Thus we find one great exception To the rule denying action To a true amorphous pupa. Tribe the third, Strationina, Mostly have a water larva, Long, and tapering off to nothing, But divided into segments, Marked most deeply and distinctly. When the pupa stage is coming, Then the larva skin turns rigid, Losing nothing of its figure; And the pupa stays within it Till the season for emerging. The perfect insect or imago Has the body flat and widened, Looking much as though flatironed, Wider than the wings when closely Laid incumbent on each other, Always nipped in at the middle; 
And we find on the scutellum

Many spines all pointing backwards.

The antennie have no bristle,

But are very often elbowed, And the joints beyond the middle

Form a close mass, manyjointed.

Tribe or order TABANINA:

Sarage wives and gentle husbands;

All the females are bloodthirsty,

Drinking deep the blood of cattle;

All the males are kind and gentle,

Basking on the leaves or flowers.

Their antennæ are so varied

As to make it rather puzzling

Very clearly to describe them;

But they may be called threejointed,

Only noting that in many

The last joint appears divided

Into six or seven others.

Mouth composed of many lancets,

Separately formed for cutting,

If united formed for piercing;

But 'tis only in the ladies

That we find those fearful lancets,

Often sticking out quite spearlike;

Body stout and often hairy,

Often smooth and almost globose,

Always nipped in at the middle. 
Tribe or order Asilina

Feed on other flies or insects.

They have a sharp beak or rostrum,

Formed, as in the last, of lancets,

Hanging down and not porrected,

Or stretched out at length before them.

With this beak they pierce their victims,

And then, having thus transfixed them,

Fly with living prey suspended

Helpless underneath their bodies

Until they have sucked its juices.

Their antennæ are fivejointed,

With a very few exceptions,

And in these the joints are seven ;

The form always is elongate,

Body mostly rough and hairy,

Never nipped in at the middle.

Next them come the gay Syrphina,

Beautiful and useful insects :

Beautiful and gaily banded

In the state of perfect insects,

Hanging, in the air suspended,

Over leaves and over flowers;

Useful because in the larva

Feeding mostly upon plantlice.

In the summer we may hear them

Floating in the air and humming; 
'Tis a wellknown sound of summer'. Their antennæ are threejointed, And from out the third there issues, Sideways or in front, a bristle. Their mouth is a large and elbowed Sucking tube, bent in the middle.

Next these come the true Muscina, Swarming in such countless numbers : These are all the flies domestic, In our houses, in our windews, In our chambers, in our larders, Wandering over food and flowers, Walking gravely on the ceiling, 'Gainst the laws of gravitation, Without any fear of falling,

Raising many sage conjectures, Philosophic speculations;

Always floating round the flycage In their gay aërial gambles. These are denizens of summer. Their proboscis is retractile, In a hollow of the visage, From which it protrudes at pleasure; At its tip it has two suckers, Large and oval: watch the housefly, See it use this busy sucker On some sugar spread on purpose, 
Then you'll understand its action. Their antennæ are threejointed, And their body short and hairy, Always nipped in at the middle. Where, you ask, live all their larvæ? These, my child, are very various, And are always known as maggots. Some devour the living bodies Of the larve of the Scale Wings, Some eat flesh that's putrefying, Some eat leaves and some eat branches, Some eat roots and some eat flowers, Some eat cheese and others bacon, Hundreds eat up filth of all sorts: Truly scavengers of Nature!

Lastly rank Hippoвoscina, Wonderful in transformations, Pupiparous, nymphiparous : Thus philosophers have called them, Seeing that the perfect female Perfect chrysalis produces. Of the ego and of the larva Entomologists know nothing: They exist and are perfected In the body of the parent. The adult and perfect insect Spends its life on sheep and horses, Hiding in their different clothing, 
Or on birds quite safely carried, Nestling close among their feathers, In their swift aërial joumeys.

\section{V.}

\section{TRIBES OF THE CLEAR IVINGS.}

In describing all the orders Of these fourwinged, clearwinged insects,

I must tell you of their larvæ, Where they live and what they feed on.

First, a tribe of caterpillars, As of butterflies and night moths, Living in the woods and hedges, On the juicy green leaves feeding, And resembling, too, the larræ Of the butterflies and night moths In the art of spinning cases, Inside which they change to pupæ. When the sawfly, these are Sawflies, When the sawfly once emerges

From one of these gluey cases, 
And you look at its antennæ

For some mark whereby to know it,

You will fail ; they are so varied

'Tis impossible to fix on

Any definite description :

Some are linobbed and some are threadlike,

Some are forked and some are fanlike.

All have four wings, clear and glittering,

And a thick and fleshy body,

Uniform throughout in thickness,

Not nipped in and spindlewaisted,

Like a wasp or like a spider :

They have all the feet fivejointed,

Fore shanks twospurred at the summit;

One sex only bears a weapon

Near the tail, beneath the body,

Sharply notched and very sawlike,

And with this she quickly pierces

A young leaf or juicy sucker,

And her eggs sedately places

In the wound she has created;

From this saw we call them Sawflies,

Sawflies or Tenthredinina.

Next, a tribe with footless larvæ,

White, and fat, and stupid maggots,

On the solid timber feeding,

Burrowing deep into its substance,

Leaving galleries behind them: 
They have long and thin antennæ, Gently tapering to the summit; Wings transparent and loud humming, Fore shanks onespurred at the summit, And the feet are all fivejointed; Body uniformly rounded, Not nipped in and slenderraisted, And the tail is like an augur, Formed for boring into timber; If you ask me wherefore boring, What its use and what its object, I should quickly give, this reason, That the fly may safe deposit Eggs in every excavation, Eggs from which the infant larvæ Soon emerging bore still deeper, Deeper still into the timber. Let us call them Siricina. All the oakapples and inkgalls, All the cherrygalls and nutgalls, All the bitter Dead Sea apples, All the beautiful oakspangles, And those freaks of sportive Nature Called by children wild mossroses, Found in summer in the hedgerows; All these and a hundred others Quite as strange, and some far stranger, Are the work of puny insects, 
That we always call the Gallflies,

Or in Science Cripipsina.

These most wonderful formations,

Nurseries of gallfly larvæ,

Little white and footless maggots,

Are not built by skill instinctive

Of the quiet pent up inmate,

$\mathrm{Or}_{\mathrm{r}}$ its winged and wandering parent,

But are merely strange distortions,

Caused by buoyant sap diverted

From the true and proper channels;

Yet how uniformly fashioned!

How alike in size and figure

Those each kind of fly produces!

How unlike to every other !

All the Gallflies are small insects,

With antennæ very simple,

And with bodies flattened sideways,

And divided in the middle

Into nearly equal portions,

Called the abdomen and thoras;

And the female has a borer,

Almost all Gallflies are female,

With which instrument she pierces

Leaves or tiny twiglilie branches,

Laying eggs within the fissure;

Her clear wings are almost rayless,

And her feet are all fivejointed. 
Next to Gallflies come Ichneumons ;

Insect parasites we call them, For the grubs or footless maggots, From which come the fly Ichneumons, Live concealed within the bodies Of all other linds of insects, But in caterpillars chiefly Of the butterflies and night moths : On the living flesh they fatten. When the time arrives for changing, When the butterfly should issue From its still and deathlike pupa, Then from out that shrouded coffin Comes the parasite ichneumon, With its wings all bright and shiv'ring, Quite transparent, often tinted Like the evanescent rainbow. They are insects slenderwaisted, And their tail is armed with bristles, Three long, sharp and piercing bristles, Which they plunge into their victims, And then leave an egg within them. Most of them have feet fivejointed, But a few, minute and burnished, Like winged gems so bright their colours, Have the feet four and threejointed. All the tribe we call Ichneumons, Parasites, Ichneumoniva. 
Next, the Ruloywasps invite us, Clad in mail of gorgeous colours, Blue and green, carmine and purple, Gliding over walls or palings. Who is there that has not watched them, As with vibrating antennæ They inspect each crack and cranny, Seeking out the nests of Wallwasps, Masonbees, or bees that build in Posts, or mortared walls, or sandbanks, Forming there the cosy dwellings, Dwellings for their future young ones? When these dwellings she discovers,

The sly rubywasp deposits All her eggs among the larvæ, With a weapon telescopicFashioned, joint in joint retractile ; And her young, when hatched, devour up All the food that was provided For the young of Bees and Wallwasps. Let us call them Chrysidina, Rubywasps or Chrysidina:

Their antennæ short and elbowed, Their wings clear and almost rayless, Their feet always are firejointed, Their waist is almost divided, But the two parts are united By a very short peduncle. 
Next these come the stinging insects, Bees and Wasps, Sandwasps and Pismires;

All of them with feet fivejointed.

First of these, the Bees, Apina, Called by authors Anthophila, Or in English flowerlovers, For they fly among the flowers, Revelling in all their sweetness, Gathering pollen, sucking nectar, Changing these to wax and honey; Building cells with skilful neatness, Waxen cells, and all sixsided, Waxen cells to hold their young ones. Many live in crowded cities, Many thousands in a city, Like a kingdom or a queendom, Female sovereign, drones and workers. Their antennæ stout and elbowed; Fore wings flat and never folded; Hind shanks flattened out and bristly, Formed for carrying loads of pollen; Body joined by a peduncle, Armed with sting acutely stinging. Next, the Bees, the Wasps, Vespina, Make the cells but not the honey, Build with skill their spacious mansions, Build their cells and combs with paper, Paper of the finest texture, 
Paper also manufactured

By these energetic workmen.

In these buildings, in these mansions,

Wasps will multiply by thousands,

Sovereign queen, and drones and workers.

Their antennæ somewhat elbowed ;

Each fore wing is folded lengthwise ;

Body joined by a peduncle,

And their tail is always furnished

With a sting of fearful power ;

Their hind shanks are plain and simple,

Formed not for collecting pollen.

Such, in brief, are the Vespina, Black and yellow Wasps, Vespina.

Sandwasps follow next in order, Sandwasps, Fossors, or Sphecina, Insects that delight to burrow.

In the soft and crumbling sandbanks,

Making little excavations

For their maggot young to live in.

Sandwasps do not live in cities,

But in solitude so cheerless,

And away from all companions:

You may see them in the meadows,

Catching flies and even spiders,

Justice vengeful but poetic, And the Cimicina, Bugflies;

These they numb with subtle poison 
That deprives them of all motion,

Yet seems scarcely to be fatal,

So long they retain their freshness;

Thus numbed, they, poor things, are carried

By the predatory Sandwasps,

And safe stowed within their burrows,

For the maggot young to feed on.

Their antennæ always elbowed,

Rather short and almost simple:

Fore wings flat and never folded ;

Fore legs armed with spines for digging;

Hind legs also spined, for lifting

All the spiders, flies and bugflies,

That they carry to their burrows :

Body nipped in at the middle,

The waist thin and often threadlike.

Such are Sandwasps or Sphecina,

Sandwasps, Woodwasps, or Sphecina.

Watch the ant, thou little maiden !

Mark her labours, and learn wisdom!

Need I tell thee, need I show thee,

How she plies her ceaseless duty;

How she excavates her dwellings;

How she feeds her helpless offspring,

How she tends them, how she loves them,

How, in sunshine bright, she suns them,

How she moves them, when in danger,

From a foe or passing shower; 
How she keeps the stolid plantlice, That her young may sip their honey?

Watch the ant, thou gentle maiden!

Mark her wise ways, and learn wisdom !

Note her subterranean cities,

Where the streets are thronged with passers,

Where the kings and queens, and workers,

All intent upon their duty,

Meet in galleries and pathways;

Kings and queens with wings in autumn;

Workers, always working, wingless ;

All have their antennæe elbowed,

All are nipped in or thinwaisted;

Queen and workers, too, are furnished

With a sting so small and pungent;

All have feet that are fivejointed.

Everybody knows the Pismires,

Pismires, Ants, or Formicina.

Watch them work, thou little maiden!

Mark their wise ways, and learn wisdom! 


\section{VI.}

\section{TRIBES OF THE CASE WINGS.}

Gentle Laura! silkhaired Laura!

Sunny, funny, romping Laura !

Come with me into the forest;

Come with me into the meadow ;

Come with me to Hokempokem,

Where the bubbling brook runs sparkling,

Or beneath the steep bank darkling;

Come with net, for beetles hunting;

Come with boxes, beetlehunting;

Come, the young and old together:

I will tell you all about them,

How to know them, where to find them.

Sit down on this bank of flowers,

Bank of buttercups and daisies,

While the trembling sunshine, glinting

Through the murmuring, rustling aspen,

Jocund dances all around us;

Sit down, young and old together.

First in order come the Tigers,

Tigers of the insect races ; 
For they all are fierce and savage, Like their namesakes of the jungle, Preying upon living victims ; They are mostly gay and glittering, And fly swiftly in the sunshine; Their antennæ are quite simple, Tapering gradual to the summit. Tiger Beetles we may call them, Tigers or Cicindelina.

Next in order, the Ground Beetles, Also feed on living insects ; But they wander seldom flying, And most often in the nighttime; Still a few delight in sunshine, And these few are called sunshiners; Their antennæ all are tapering, And we name them Carabina.

Now we come to Water Beetles, Beetles that can swim like fishes, Live and dive beneath the water, And there hunt for other insects, Catch and kill them without mercy, Just as Tigers or Ground Beetles; Their antennæ, too, are tapering, And we call them Drisiscina.

Last of these tyrannic beetles, Feeding on their living victims, Feeding also on dead bodies, 
Come these long and narrow fellows, That turn up their tails in anger If you tease them, if you touch them; Their antennæ like a necklace Made of black pearls strung together, With the biggest always outwards, Almost always sliced off sideways. They have stout and square wing cases, And their body is uncovered, So that they can turn their tails up. Firby called them all Rove Beetles; We will say Staphrumina.

There are other Water Beetles, Beetles of all sorts and sizes, Swimming, diving in the water, Living in the water gardens, Feeding on the leaves and flowers; Their antennæ are not simple, Sticking straight out from the forehead, But are always knobbed, and hidden In a hole beneath the skull cap: These we call Hydrophilina.

Next come these gay Sexton Beetles, Gay, but smelling, O! so horrid! For they feed on putrid bodies; They have also linobbed antennæ, And the lnob is hard and solid: We will call all such Silphisa, 
Sexton Beetles or Silphina.

Look at this bright green rose beetle, Feeding in the heart of flowers, On the pollen from the anthers; And at this great buzzing watchman, He delights in something nasty; And at this forlorn oockchaffer, Shaken from the tree above us, Where he feasted on the green leaves: All these three have knobbed antennæ, And the knobs are all divided Into thin and flat divisions. These we call Scarabeina; We call all such beetles Chaffers, Chaffers or Scarabæina.

What is this but a Click Beetle?

If upon its back you lay it, Up it leaps with sudden snapping. Now examine its antennæ ; They are slim throughout and serrate, Serrate, that is notched or sawlike. These may all be called Click Beetles, Clicks or Snaps, Elaterina. "Tell me what are Soldiers, Sailors, Always crawling on the pathways, Poor things! always getting trod on, Always climbing up the fences, Always buzzing in the hedges, 
Clambering on the grass and flowers;

Here is one upon a harebell."

They are called Telephorina;

They are soft and very tender,

Not at all like hardcased beetles;

Their antennæ are quite simple,

Neither serrated nor clublike.

Pray remember all these beetles,

These nine tribes which I. have shown you, Always have the feet fivejointed.

Now then come a tribe so diverse That I cannot well describe them. Their antennæ greatly vary ; Some are tapering, some are clublike, Some are comblike, some are sawlike, Some are threadlike, some are fanlilie; But their feet are always constant, Fore and middle pairs fivejointed, Hind pair always but fourjointed. Let us fix on what to call them : Heteromera, Blapsixa ; These two names are sometimes given, But I think I like Blapsina.

Next in order come the Weevils, Little elephants, longsnouted, And their snouts antennæ bearing; The antennæ, too, are elbowed, First bent backwards and then forwards : 
We can call them Snouts or Weevils, Or else Curcultonina.

These are followed by the Longhorns. This is one so sweetly scented, Scented like the oil of roses, Oil or attar as you like it; This is called the great musk beetle. But they are not all sweetsmelling, Yet they all have long antennæ, Longer even than the body, Long and gently tapering outwards. These we call Cenambicina. Look at these plump shining beauties, Fat and round as any dumpling, Often decked in brilliant colours, Green and gold and rainbowtinted ; All their feet flat and fourjointed; Their antennæ like a necklace, All the pearls alike in bigness : These we call Chrysomedisa. Lastly, clad in mail of scarlet, Or in clearest, purest yellow, And in either case blackspotted, Are these round and pretty beetles, Which we know as Aphisfeeders; They have short and clubbed antennæ, And their feet are but threejointed. Evergbody seems to like them. 
Ladybirds we mostly call them, Ladybirds, Coccineluina, Ladycows if you prefer it; But why birds or cows I know not: 'They are very pretty beetles.

There's the end of my descriptions; Now I'll tell you where to find them, How to catch them: but the pupil, Tired with such a lengthy lesson, Bounded off to join her sisters, Who, with Ellen and Maria, Dipping deep in Holiempokem, Fished that limpid stream for minnows, Sticklebacks and sly stone loaches. Vainly did I call for Laura; She had reached the youthful fishers; So I left the bank and joined them. 


\section{VII.}

\section{TRIBES OF THE ROOF WINGS.}

Up ! the early skylark, Laura, Leader of the daybreak chorus, Is inviting us. 'The songsters Of the wood and of the meadow Join with him in paying tribute To their bountiful Creator, Offering up the hymn of morning, Hymn of tuneful adoration, All their happiness proclaiming: Happiness is adoration. Still the insect world is sleeping, Still the world of plants is sleeping. Ah! how true that flowers can slumber! See these closed and brilliant petals; See these folded leares of trefoil ; See these buds and blossoms hanging Heavily on slender footstalks :

All are wrapt in peaceful slumbers,

Peaceful and refreshing slumbers, That, all undisturbed, have lasted 
'Through the short, sweet night of summer, And will last till heat, returning, Dissipates the drops that glitter On the green grass, on the hedges, Showering on us if we touch them. Even now the sunbeams, slanting, Gild the morning mist with glory, Fill the trembling gems with colours, Colours brilliantly prismatic, Like disintegrated rainbows. Up! the early skylark, Laura, Is inviting us to study.

Let us next observe the Roof Wings, Insects that are truly netwinged, But distinguished by their pupæ, And their feet, which are fivejointed, From the true and proper Net Wings:

Class Stegoptera we call them.

First, the Ant Lions, so famous

In all ages, in all countries, Theme of students, theme of sages ;

Crafty Mrrmeleontina.

The wise larva makes a pitfall In the crumbling sand of summer, Shaping it like cone inverted: Into this the pismires wander, Pismires, beetles, and all insects ; And, once having passed the margin, 
Find within a treacherous footing, Made of sand so granulated That it yields beneath the footsteps; And the helpless, fated victim Slides unconscious to the bottom, Where the dire Ant Lion larva, With his fearful jaws wide open, Waits in ambush to receive it; But sometimes a passing shower Has the grains of sand united, And the insect finds a footing, And is just about escaping: Then the sage Ant Lion larva Jerks the stones and sand upon him, Till the victim, quite exhausted, Struggles slowly to the bottom. The larva, like a bloated spider, Which in form he much resembles, Seizes on the luckless insect, Pierces it with jaws tremendous, And then sucks out all its juices. When become a perfect insect, This Ant Lion, once so savage, Is a very harmless creature; Having feelers manyjointed, Manifestly thickened outwards ; Having four wings just like network, Very long and rather narrow; 
Body long and very slender, With a rather small prothorax.

These Ant Lions are not British, So that we shall never find them In our country walks together. Next to these, the Aphis Lions, Lacewinged Flies, or simply Lace Wings, hinown as Hemerobita.

First, their eggs must claim attention, Seated on a long peduncle, Like some very slender fungus Growing from the leaves or branches. In the bright, long days of summer, When the little larva hatches It crawls down the long peduncle, And then, roving o'er the surface Of the leaf that formed its cradle, Finds some Aphides or plantlice, Very small and very tender, And so one by one devours them. Thus it spends its whole existence In devouring hosts of plantlice. The imago has four clear wings, All alike and very ample, Crossed with slender rays like lacework, And a small and short prothorax;

Its antennæ manyjointed, Pather long and rather slender, 
Never growing thicker outwards ; Its eyes very often golden, And its body bright green coloured : Lovely looking, but illsmelling. After Lacewinged Flies, or Lace Wings, Comes a tribe that's half aquatic, Larvæ swimming in the water, And the perfect insects flying Over pond and over river. Now, at early dawn, we find them. Sleeping on the broadleaved bullrush; Often, falling in the water, They become the prey of fishes. These we call Corydalina. All the winged or perfect insects Have a large, distinct prothorax, Sometimes square, sometimes cylindric, Never narrow as in Lace Wings;

Feelers long and manyjointed, Mostly tapering to the summit. Scorpionflies, or Panorpina, Seem to follow next in order. Larva very little noted;

But a certain learned doctor Found one in decaying timber, Fed it a long time on apple, Kept it till it was a pupa, And at last a brisk imago. 
Head of the adult imago

Lengthened out and very slender,

Like a bird's beak bending downwards;

Feelers long and manyjointed,

Taper gradually outwards;

All their wings alike and narrow,

Rayed across but never netlike;

Body small, and in the male sex

Ending in a kind of forceps,

Like the scorpion's tail so horrid.

Snakeflies, or Raphidina,

Have a head that's large and oval ;

A prothorax long and necklike, Often moring sideways, snakelike;

Feelers short and manyjointed,

Taper gradually outwards ;

Wings alike and always netlike.

Larra found in bark of timber,

Where, some say, it feeds on insects ;

Whether this be true I know not.

Caddisflies, Phriganeina,

Simulate the moths so nearly,

That the student first begimning

Finds the likeness quite confusing.

They have hairy wings and bodies;

Long antennæ, manyjointed,

Very, very manyjointed,

Always stretched out straight before them; 
The hind wings are folded lengthwise

Underneath the hairy fore wings.

Caddis larvæ are aquatic, Living always in the water, In a case of their own making. Habitation locomotive; 'Tis of wonderful construction ; Sometimes made of tiny pebbles, Sometimes of the smallest snailshells, Sometimes of small bits of rushes, Or of leaves long soaked in water, Always neatly joined together, Always joined with sillk together. In these wellconstructed mansions Every Caddis has its dwelling. Peaching out its head and fore legs, It devours the sodden edges Of the waterweeds and grasses, And the leaves of weeping willows Gently dipping under water. 


\section{TRIBES OF THE NET WINGS.}

Hasten to the evening hay field, Whence the sound of merry voices, Shouts of laughter as of children, Some half smothering the others, Seem to float with such distinctness In the atmosphere above us, Mixed with fragrance as delightful As the sounds of fun and frolic. Still the happy field is distant. As we thread the lanes together, I will tell thee of the Net Wings, Some of which have wings not netlike; Such are Ticklers, or Thripsina, Insignificantly little, Nestling close in every flower, Larva, pupa and imago, Gnawing round the purple petals Of the Fuchsia new opening, Making these and other flowers That attract their greedy notice 
Dim and desolate to look at.

Let us glance at the imago :

It has moderate antennæ,

Which are six or sevenjointed;

Wings alike and four in number,

Narrow, long, unfolded, rayless ;

Body long and rather pointed;

Feet prehensile and twojointed.

Next the Tickilers, the Psocina

Are the least, and most aluundant;

Little, active imps of summer ;

Every tree and every hedgerow

Seems to swarm with these Psocina,

Larra, pupa and imago,

Winged and wingless all together.

On the trunks of these old elm trees,

Tall and miserably shrouded,

Shorn at once of use and beauty,

We shall find, in cracks and crannies

Of the bark so gnarled and knotted,

Numbers of these small Psocina,

Running like a host of spiders,

Looking like a host of plantlice,

But they run a great deal faster.

When with wings these mites are furnished,

Then the hind wings are the smaller,

And are never folded lengthwise;

Their ejes small, and round, and distant ; 
'I'heir antennæ simple, slender, Long and very manyjointed; And their feet are all threejointed. Dayflies, or Ephemerixa, Form a wellknown tribe or order, Haring small and short antennæe, Rather large and netlike fore wings, Very small and netlike hind wings. When these pretty flies are resting All the wings are pointed upwards, Back to back, appressed together. They have rather slender bodies, Never nipped in at the middle; Very long and thin tail bristles, Two and sometimes three in number; Fore legs very long and slender, And their feet are all fivejointed. 'Tis a pleasant sight at even To observe the Dayflies dancing Over river, over meadow; 'T'is the choral dance of poets, "Tis the poetry of motion :

Pinions briskly moved while rising, Stretched out motionless while floating, Like the lightest feather, downwards. Dayfly larvæ are aquatic, Living, feeding in the water, Breathing by their lungs external; 
And their pupæ have two stages :

First, with wings rolled up in cases,

Much like many other pupæ ;

Next, with wings spread out for flying,

And adapted, too, for flying,

Being thus a flying pupa.

It is strange to see a pupa,

Settling, may be, on our clothing,

Casting off its outer garment, And emerging as a Dayfly,

Most elaborately fashioned,

But the creature of an hour.

Here the bard might draw a moral

From the evanescent Dayfly,

Might improve the apt occasion,

As his tribe have done before him;

But the insect world is wondrous

As a whole and altogether:

$\mathrm{He}$ who tries to read it rightly

Finds it a perpetual sermon,

Fraught with the profoundest teaching.

Now we come to kings and princes,

Princes of the world of insects.

See Lindenia formosa,

With its brilliant hue cærulean ;

See it hover o'er the waters,

Poised aloft on rustling pinions ;

Then, as by some sudden impulse, 
Darting off on distant errand, And ere long again returning, And again, on rustling pinions, Hovering above the waters. Dragonflies, Libellulina; Horse Stingers the vulgar call them, Falsely, ignorantly call them. They have short and small antennæ, Bristlelike, and eyes enormous; Wings alike, and finely netted With innumerable meshes; Hind wings at the base are broadest; All the wings spread horizontal When the Dragonfly is resting:

Body very long and slender, Often very gaily coloured;

In Lindenia formosa

'Tis of purest, brightest azure :

Feet in all the tribe threejointed. All these creatures love the sunshine, Hawking after living insects, Which they chase and capture flying, And then, on a dead twig perching, Leisurely devour their victim Ere its brief, brief life has parted. All their larvæ are aquatic, Feeding on the worms and insects Which abound on muddy bottoms 
Of all stagnant pools and ditches.

Pupa equally voracious,

Somewhat shorter than the larra,

Stout and squat, and very toadlike.

When about to change its station,

To become a winged imago,

Then it crawls out of the water,

Fixing to a reed or grass stalk,

Bursting through its shrivelled cerecloth,

Opes its broad wings in the sunshine,

Leaves the castoff skin adhering To the reed or to the grass stalk, And then mounts on glittering pinions.

Demoiselles, Agrionina, Are but Dragonflies in little: They are somewhat hammerheaded; Their eyes rather small and distant;

Feelers very small and pointed;

Wings alike and rather narrow, Always narrowed towards the body, When at rest appressed together, Back to back above the body, Never stretching straight, porrected, At right angles with the body; Body very long and slender, Often blue or black bluespotted. Nature has no lovelier colour Than the blue of these long bodies; 
Some few have these lengthened bodies

Green and brilliantly metallic,

And the wings more ample, clouded

With the deepest, richest purple.

Feet of Demoiselles threejointed.

These, too, have aquatic larræ,

And aquatic, greedy pupæ,

But the pupæ are elongate,

And not short and squat and toadlike.

Most attractive of the Net Wings,

For their wonderworking instinct,

Governing enormous nations,

As with superhuman wisdom, Are the White Ants, Termetina;

And though White Ants are not British,

Still we should know something of them.

White Ants, Laura, live in cities,

Populous as those of China,

And constructed, too, with science,

Full of galleries and pathways,

Full of viaducts and tunnels,

Full of terraces and bridges,

Storehouses and regal chambers,

Full of kings and queens and rulers,

Full of energetic workmen,

Full of fiercely fighting soldiers.

All are but the eridences

Of an intellect allperfect 
That with undisputed fiat

Wills and carries out these wonders.

Man may learn a useful lesson

From these tiny, busy creatures;

Learn how unity of purpose

Ever will obtain its object.

Silently the work progresses.

Now destruction, not construction :

First they seem to hew the timber,

Then to mix the plastic mortar,

Then to build their habitation,

Working mostly in the forest,

Where their doings are unheeded,

But sometimes in human dwellings,

And 'tis there the devastation

Tells upon our purse and temper.

Chairs and tables, drawers and bedsteads,

Fall a prey to these destroyers, And, what seems the greatest wonder, All their handywork is hidden.

One begins a meal of table, At the leg just where it touches The smooth floor on which 'tis standing.

Having thus secured a footing, Others come in quick succession, Myriads come, and soon devour All the wood except the surface, Which is always left with caution, 
Just as thin as any wafer; Thus the damage goes unnoticed Till the table is required; Then it crumbles into atoms Underneath the slightest pressure. All but lings and queens are wingless, And the kings and queens are furnished With wings only for a season, Just to give the power of flying From their former habitation Forth to found another kingdom. When these royalties have settled, Then they lose the wings that bore them: Some have seen the creatures turning Back their heads, and briskly biting All four wings from off the thorax; And, as soon as thus selfcrippled, Straggling workers seem to find them, And thenceforward to entrust them With unlimited dominion,

Quickly raising round about them

All the buildings of a city.

Laura, there are forms so varied In the mighty White Ant city, Forms of kings and queens and soldier's, Workmen of all sorts and sizes, Larva, pupa and imago, That I cannot now describe them. 
One word only of the rulers:

They have feelers short and jointed,

Not unlike a lady's necklace ;

Wings, that is at first, unfolded,

All four quite alike in figure;

And their feet are all fourjointed.

Lastly, come the heavy Stoneflies,

Innown in Science as Perlina,

Very like domestic crickets,

But are riverloving insects ;

Their head rather broad and flattened;

Their eyes small, and round, and distant;

Fore wings flat, and hind wings folded,

Larger, broader than the fore wings.

Larvæ more than half aquatic,

Nimbly swimming in the water,

Nimbly diving in the water,

Nimbly running on the bottom,

Hiding under little pebbles,

Often coming out, and creeping

On the bank and on the grasses,

Crawling up the trunks of willows, Hiding in the cracks and crannies.

When the pupa is quite ready

To become a winged imago,

Then it grasps the bark of willows,

Or the rounded stems of rushes,

$\mathrm{Or}$ the pliant blades of grasses, 
By its hooked claws firmly anchored; Then the back splits open lengthwise, And the perfect fly emerges, Flying softly" o'er the streamlet, To become the prey of fishes. Seeing this, the wily angler Makes an imitation Stonefly, Which, the fatal hook concealing,

Is appended to the catgut, And dropped softly on the surface Of the bright and dimpled river, And there, scarce a moment floating, Tempts the lurking trout or grayling Irresistibly to seize it. But I've talked into the hay field, Where the children all are playing; So we'll have no more of Stoneflies, But a game of hay field romping. 


\section{TRIBES OF THE STRAIGHT WINGS.}

Come with me, and I will tell thee Of the Earwigs, and Cockroaches Vulgarly yclept Blackbeetles ; Crickets, Grasshoppers and Locusts ; These, with Walking Leaves or Spectres, And the praying, fighting Mantis, Constitute a great division, Class Orthoptera intituled. Where the sun beneath the tropics Perpendicularly blazes, There Orthoptera, abounding, Devastate the plain and forest ; In our cold and cloudy island They are small and few in number. Some are walkers, some are leapers.

First of walliers come the Earwigs, Earwigs or Forficulina; Feeding on the lovely petals Of our best and choicest flowers, Hiding in all sorts of crannies 
From the sunshine in the daytime, Crawling, feeding in the nighttime; Their antennæ manyjointed, Gently tapering to the summit, And the joints are swollen, beadlike, Beads strung in a tiny necklace; The fore wings are square and shortened, Leaving all the body naked, Just as in the queer Rove Beetles, Which they very much resemble; But the hind wings, quite transparent, Like a lady's fan are folded Neatly up beneath the fore wings, And when opened out are earshaped, Very beautiful to gaze on ; All the legs are very simple, And the feet are all threejointed; At the tail we find a weapon Very like a pair of pincers, And with this 'tis said the Earwigs Open and fold up the hind wings; You must watch them and observe it :

I have never had that pleasure. Next in order, the Cockroaches, Swarming in our cockney kitchens, In the cupboard, in the pantry, In the breadpan, in the meatsafe, Every kind of food devouring, 
Every lind of food defiling, And most disagreeably smelling, Greedy gluttons, eating all things, Hiding always in the daytime, Hating daylight, hating sunshine, Up and eating in the nighttime. Their antennæ long and tapering, Long and thin, and very threadlike, Very, very manyjointed;

Head bent down beneath the thorax;

Fore wings large, and tough and leathery, Folding over one another,

Folding over both the hind wings;

These are folded, too, beneath them, And all lying on the body:

Their legs all alike and simple, Formed for running, not for leaping; And their feet are all fivejointed. Such are Cockroaches, Blattrixa. All the rest are merry creatures, Merry, leaping, chirping creatures, Locusts, Grasshoppers and Crickets, Loudly singing, merry chirping, Bright creations for the poet To adorn his rural song with. Crickets, first, or ACHETINA, Lead a merry life nocturnal, And, like nightingales so wakeful, 
Sing the livelong night in summer ;

Some are housed in banks and hedgerows,

Some in caverns subterranean,

Some are homed in all our houses,

Chirruping upon our hearth stones,

To the superstitious boding

Good or evil as they fancy.

Their antennæ long and slender,

Threadlike, too, and manyjointed ;

Their fore wings are short and leathery,

Folding over one another;

Their hind wings are folded fanlike,

And project beyond the fore wings,

Often curling at the summit;

Hind thighs thick, and formed for leaping,

And their feet are all threejointed.

Grasshoppers are one with Locusts,

But we must a tribe determine

Somerrhat differing from the Crickets,

Somewhat differing from the Locusts,

A tribe that we may call Gryllina;

Their antennæ manyjointed,

Long and tapering as in crickets,

But their fore wings straight and lengthen'd,

Stretching out beyond the hind wings,

Meeting rertically rooflike;

Hind wings always folded lengthwise;

Hind thighs thick and formed for leaping ; 
And their feet are all fourjointed.

These Gryllina are diurnal,

Leaping, singing in the sunshine.

Lastly, Grasshoppers and Locusts,

For I find I must unite them

In one tribe, called Locustina ;

Their antennæ thickened outwards,

Short and often rather clublike,

And not very manyjointed;

Their wings formed as in Gryllina;

Hind thighs thick, and formed for leaping ;

And the feet are all fivejointed.

\section{$\mathrm{X}$.}

TRIBES OF THE HALF WINGS.

One more walk, and one more lesson. Get thy nets and boxes ready ; Let us go a longer journey, By the North Kent Rail to Dartford, And thence to the wood of Darenth. Can we not persuade thy father 
For this once to come and join us?

I shall tell thee of the Half Wings,

Class Hemiptera, or Half Wings.

I will show thee many of them

On the trees and on the flowers, And, with waternet longhandled, We will get the rest from water ;

Here and there in that great forest, Stretching northward, stretching southward, Stretching eastward, stretching westward, There are little pools of water Filled with insect life aquatic. Place first all the Bugflies proper, With their long and large antennæ Stretched out visibly before them; Fore wings always of two textures ; Where they fit on to the body They are thick and tough like leather, But the tips are quite transparent, Thin and flexible and filmy,

One laid on the other crosswise :

All their legs are very simple,

Formed for running, not for leaping, And their feet are all threejointed. On the sap of plants they fatten, Sucking it with pointed rostrum. Oh, they smell so very nasty !

Like the bug we find in houses; 
Even that's a Bugfly proper, One whose wings are undeveloped. All are known as Cimicina.

Next them come the Water Walkers;

They all walk upon the water;

On each pond and stream you find them,

Skimming safely on the surface, Safely as we tread the pathways,

Without any chance of sinking;

Their fore wings are long and narrow,

Tough from end to end like leather,

With their edges folded over;

All their feet, too, are threejointed, And their body straight and narrow,

Like a bit of stick just broken :

Water Wallers, Water Runners ;

If you like, Hydronetrina.

Following, and next in order, Though I rather would avoid them, Are those flat and ugly creatures, Crawling slowly on the bottom, On the muddy, slimy bottom, Of the stagnant ponds and ditches, Feeding upon little fishes, Or the grubs of water insects. Their antennæ are quite hidden Underneath the poking forehead; Their fore wings, like those of Bugflies, 
Are of two distinctest textures, Tough and leathery next the body, Thin and quite transparent outwards, And there always folded crosswise; All their feet are but twojointed; All their legs are formed for crawling, Not for leaping nor for swimming ; And their tail is two long bristles. Water Scorpions I call them, Water Scorpions, or Nepina.

Next to these the Water Boatmen Follow in the proper order: Their antennæ are quite hidden; Their fore wings are of two textures, And are always folded crosswise, Just exactly as in Bugflies; And their fore legs formed for grasping, All the rest are formed for swiniming; And their feet are but twojointed. Let us watch them in the water, In the bright, transparent water, On their backs for ever swimming; Don't they look the wrong way upwards? Yet their movements all are graceful. I call them Notonectiva.

In the country that we live in Skies are very often cloudy, And the air is damp and chilly; 
So we have but few Cicadas,

Merry songsters of the summer

Where the skies are blue and cloudless.

But these little, jumping creatures,

Which we often call Froghoppers,

Are the Englishman's Cicadas,

One alone indeed excepted,

One we find in the New Forest;

All of these are mute as Bugflies.

They have almost no antennæ,

Like the shortest, finest bristles;

Their fore wings are of one texture,

Very often quite transparent,

Sometimes coloured, sometimes clouded,

Sometimes thick and rather leathery,

Sometimes pied and gaily spotted,

But they meet together rooflike,

With straight edges, never crossing

Like the wings of Water Boatmen,

Which they very much resemble;

Their hind legs are formed for leaping,

And they leap with wondrous power,

Vaulting high, but seldom flying;

And their feet are but threejointed.

I would call them all Cicadas,

But the English word Froghopper

Will do very well for England, 
With its very small Cicadas, Froghoppers, or Crcadina.

Now we turn to lumpish insects, Fixed like scales upon the branches Of choice plants in hot stovehouses, Often, too, upon our myrtles, Very often on the apples, And sometimes upon the harthorn; These are always lady insects That thus stick upon the branches, Scalelike insects, or Coccina. Gladly I'd describe antennæ, Wings and feet, if I could find them, But from me these parts are hidden. Gentlemen are rarely met with, And 'tis said they are not scalelike, But have wings and long antennæ.

Lastly, come the noisome Plantlice; Smotherflies the farmers call them, Smothering all the growth of summer, All the tender shoots of roses, Crowding till the shoots are hidden, Leaves and buds concealed by numbers, Anchored by their beaks sapsucking, Winged and wingless all together :

Their antennæ long and waving, Gradual taper to the summit; All their wings are quite transparent, 
When they have them, and not folded, But above their backs meet rooflike; All their feet are but twojointed, And their legs not formed for leaping. These are Plantlice, Aphidina. There are many circumstances Curiously appertaining To the life of these frail Plantlice, Circumstances which not even Those most learned in the marvels That abound in lives of insects Understand, or can decipher. May be that thy ardent spirit, Laura, when it comes to ponder O'er the mysteries of creation, Shall elucidate these problems. And in all the other Orders Which I've briefly set before thee There are wonders upon wonders, Which will task thy utmost powers Of inspection and reflection. 


\section{VALEDICTION.}

LAURA! now the bard has ended

These his manifold descriptions,

With their frequent repetitions,

To thy youthful mind so needful ;

Let him give a word, at parting,

Of parental admonition.

First, in ardently pursuing

This our fascinating science,

Let thy mind be bent on learning,

Ever bent on simply learning ;

For it is alone to students,

True and ardent, are laid open

Nature's deeply hidden secrets;

And if we discover nothing

That has not been seen by others,

Still, at least, the gift of learning

Will be strengthened as we use it.

If we wish to pause in learning,

And believe our knowledge perfect,

We at once erect a floodgate,

That shuts out from all the future 
The sweet waters of instruction,

The true sources of improvement.

Look on Nature as a volume,

Ever open to inspection,

In which characters are written

By the hand of the Almighty ;

Reverently turn its pages.

Listen not to those who tell thee

That ours is a worthless study,

Worthless from the very smallness

Of the creatures that we study:

Solomon, of men the wisest,

Taught a very different lesson.

Ponderous size and giant stature

Are not attributes of greatness.

Is the whale, that ocean monarch,

More majestic in its instinct

Than the bee that makes our honey?

Then, again, when thy collection Stretches out its fair proportions, Amply filled with cognate species, Let no thoughts of money value E'er perplex thy generous nature. In regarding all these treasures,

Now so carefully collated,

Learn to estimate them solely

By their worth as sage instructors ; And should bargainmakers tempt thee 
With proposals for exchanging, Turn away in silent sorrow

Sorrow, that a trading spirit Should pollute a mind where Science Once appeared about to nestle; Silent, because words are wanting 'T'o express thy better feeling To the ears of one so hardened. This sad practice of exchanging, And dishonest bargainmaking, Is the plaguespot of the science. And the soulcramp of exchangers, Give; thou canst not give too freely; Giving is so great a pleasure That the giver is the gainer. But not only this: the giver Reaps in kind an ample measure.

Those who doubt this trutly should test it By munificently giving.

But in learning or instructing, In receiving or in giving,

In that intercourse with mankind Into which the path of Science Must inevitably lead thee, Must most innocently lead thee, Mind in all things let the conscience, Planted in thy breast by Heaven, Be thy rule and guide of conduct. 
If through life we yield obedience, Cheerful, without hesitation, To that everpresent Mentor, That infallible director, Then we find no cause for mourning, Vain or unavailing sorrow :

Memory then, like placid moonbeams, Sheds a soft and silvery lustre On the days that have departed; Happiness, with smiling features, Child of innocent employment, Brilliant as the noonday sunshine, Lights the now of our existence: Lastly, like this glow of sunset, Reddening the westward heaven, Prelude of a fair tomorrow, Hope illumines the hereafter. . 


\section{Entomologiral Saptgits.}

(TRANSLATED.)

\section{I.-THE BUTTERFLY.}

LATE, as I wandered o'er a verdant meadow, Loathsome and hairy creatures were devouring Every leaf that tempted with its greenness, Or by its fragrance.

Great was their toiling, earnest their contention, Piercing their hunger, savage their dissension, Selfish their striving, hideous their bearing,

Ugly their figure.

Next day I wandered to the verdant meadow; Each worm was spinning for himself a mantle; It was his grave shroud, and I watched him closely Wrap it around him.

Once more I wandered by the verdant meadow ; Each worm was bursting from his long confinement, Each one was spreading to the sun's bright beaming Quivering pinions. 
Hued like a rainbow, sparkling as a dew drop, Glitt'ring as gold, and lively as a swallow, Each left his grave sliroud, and in rapture winged him Up to the heavens.

Oln, then, shall man, on eartl condemned to trouble, Toilsome existence, warfare with his kindred, Build for himself his last, cold habitation,

Doomed to remain there?

No : like these creatures, trouble, toil and prison Chequer his pathway to a bright hereafter, When he shall mount him to the happy regions Made to receive him.

\section{II.-THE FIREFLY.}

AFIER the sun has sunk into the ocean Thou dost awaken from thy daylight slumber; Night is the season for thy lamp to glisten; It is thy daytime.

So will I leave to those who love his scorching, Day's ardent ruler, and, when night approaches, Offer my homage to the moon's pale glances, And the sea perfume. 


\section{III.-THE CICADA.}

HAPpy Cicada, perched on lofty branches

Deep in the forest, cheerful as a monarch,

Tasting the dew drops, making all the mountains

Echo thy chirping :

Thine is each treasure that the earth produces;

Thine is the freshness of each field and forest;

Thine are the fruits, and thine are all the flowers,

Balmy spring scatters.

Husbandmen fondly doat upon thy friendship, Knnowing thee guiltless of a thought to harm them; Thee, mortals honour, sweet and tuneful songster,

Prophet of summer.

Thee, all the muses hail a kindred being; : Thee, great Apollo orms a dear companion; Oh, it was he who gave that note of gladness, Wearisome, never.

Songskilful, earthborn, mirth and music loving, Fairylike being, free from age and suff'ring, Passionless, purified from earth's defilement, Almost a spirit. 
ANOTHER.

Drunis with the dew drop, perched on twig so lofty, Noisy Cicada, o'er the wild waste sounding, Sawlike the feet which to thy side thou pressest,

Drawing sweet music.

Try then, my beauty, tune another measure; Pan shall reward thy labours with an echo; Here, 'neath the plane tree, all my love forgetting, Woo me to slumber.

ANOTHER.

WANDERING once, I saw a spider weaving Lithesome his meshes, and a poor Cicada, Firmly entangled in the filmy network,

Chirped for his freedom.

Quickly I hastened to the child, song loving ; Quickly released him from the fearful durance; "Fly, then," said I, "with liberty I pay thee "For thy sweet music."

E. Newman, Printer, 9, Devonshire St., Bishopsyate. 


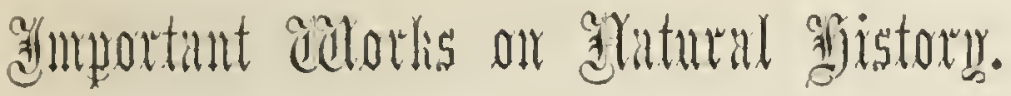

A FAMILIAR INTRODUCTION TO THE HISTORY OF INSECTS. By EDWARD NEWIAN, late President of the Entomological Society. This work contains every Instruction for Catching, Killing, Classifying, Arranging and Preserving Insects. It is written in the plainest possible phraseology, and is illustrated with a profusion of Woodeuts. Cloth lettered, and beautifully illustrated, price $12 s$.

\section{LETTERS OF RUSTICUS ON NATURAL HISTORY.}

The subjects treated of are as follows:- Insects injurious to Vegetables. Gooseberry Grub; the Fly described; Laying the Eggs ; the young Grub; Voracity of the Grubs; the Grub described; Change of Skin ; Burrows in the Earth ; Remedies. Aphis or Plant Louse; Injury it causes; Economy of. Hop Fly ; Influence on Crop of Hops; Influence on the Duty ; First Appearance of; Insect Enemies of; Remedies. American Blight. Apple Weevil; Description of; Economy of ; Remedies. Apple MLoth. Apple Grub; Economy of. Little Ermine IIoth; Yellowtail. Turnip Fly; Destructive Powers of; Economy of ; Remedies. Turnip Weeril. Turnip Aphis. Aphides in Apples, in Poplar Leaves and on Roots. Ants and Aphides. Cloth lettered, and beautifully illustrated with woodcuts, price $8 s .6 d$. This work has been carefully edited by EDward NEwJIAN, and is particularly recommended to all who are engaged in Agriculture or Horticulture, to Book Societies, and to persons making presents to young people.

THE Z00L0GIST, a Popular Monthly Magazine of Natural History, and Journal for recording Facts and Anecdotes relating to Quadrupeds, Birds, Reptiles, Fishes, Insects, Worms, Zoophytes, \&c. ; their Habits, Food, Retreats, Occasional Appearance, Migration, Nests and Young. On the 1st of every Month, price 1 s.

Loxdon: Johy Vai Voorst, 1, Paternoster Row. 
NEWMAN'S BRITISH FERNS, comprising accurate Figures, full Descriptions, List of Localities, and minute Instructions for Cultivating. Third Edition, price 18s., demy 8vo, cloth, gilt. "Mr. Newman reigns supreme as an authority on British ferns." . . . . "We most cordially recommend this work as one which, in accuracy of observation, clearness of description, and beauty of illustration, has not its equal." - Annals of Natural History. "Cannot do better than consult Mr. Newman's ' History of British Ferns.'"--IIr. Ward on Closed Glass Cases.

London: John Van Toonst, 1, Patennoster Row.

A COMPLETE LIST OF BRITISH FERNS, printed on one side, and intended for Labels, and also to facilitate the Exchange of Specimens. The somewhat conflicting Nomenclature of British Authors, from Sir J. E. Smith to the Third Edition of Newman's 'History of British Ferns,' is harmonised and given in Chronological Order, so that every one can comprehend the whole at a glance. One folio sheet, price $3 d$., by post $\pm d$.

"PUPA DIGGING." - Under this title is reprinted, at the low price of Truopence, the Rev. Mr. Greene's truly useful paper on this subject. Entomologists requiring it will please send two penny postage stamps for each copy, and one penny stamp additional for postage. The penny for postage will be sufficient, however large the number of copies ordered.

rene will be sent out without prepayment.

\section{ZOOLOGIST LIST OF BIRDS OBSERVED IN GREAT}

BRITAIN AND IRELAND, to be used for Labels, and also to facilitate the Exchange of Birds and Eggs. It is brought up to the end of 1854 , contains Latin as well as English Names, and is arranged in accordance with the Second Edition of Yarrell's 'British Birds.' Price 4d., printed on one side only, for Labels; or 5d. by post.

London: F. Newhan, 9, Deronshire St., Bishopsgate. 




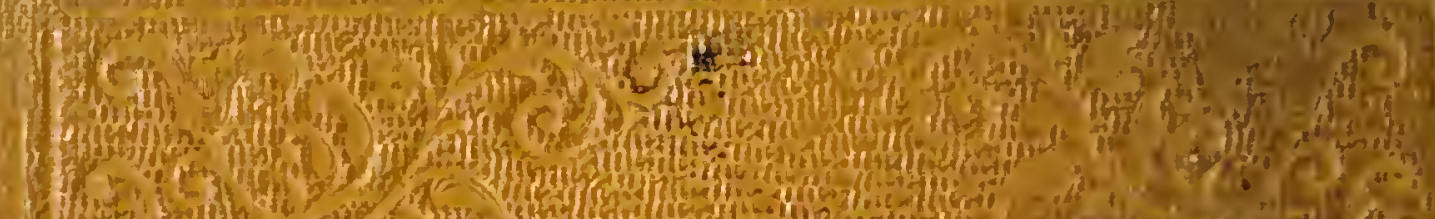
1. (1)

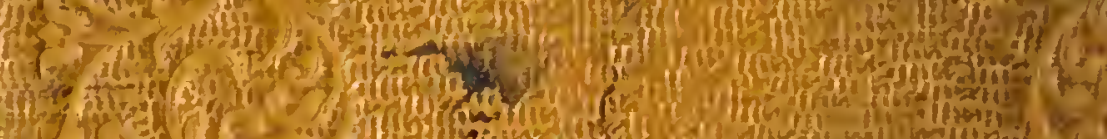

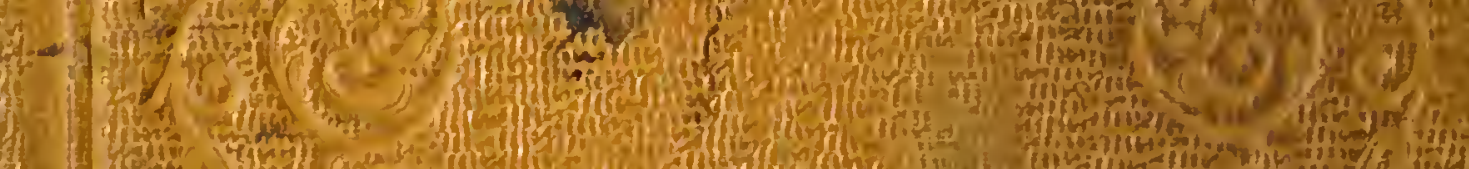
2.2 re

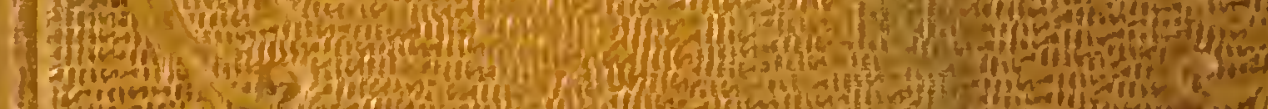
(1) 7 (2) (1)

1. (1)

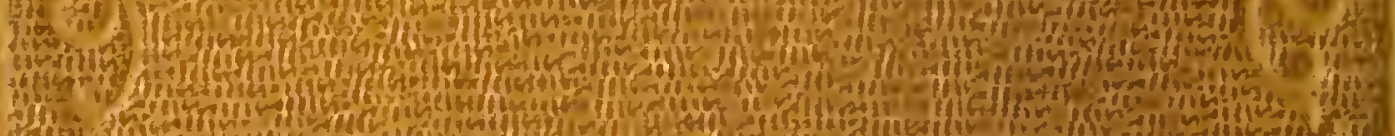

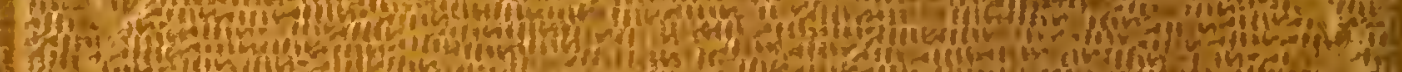

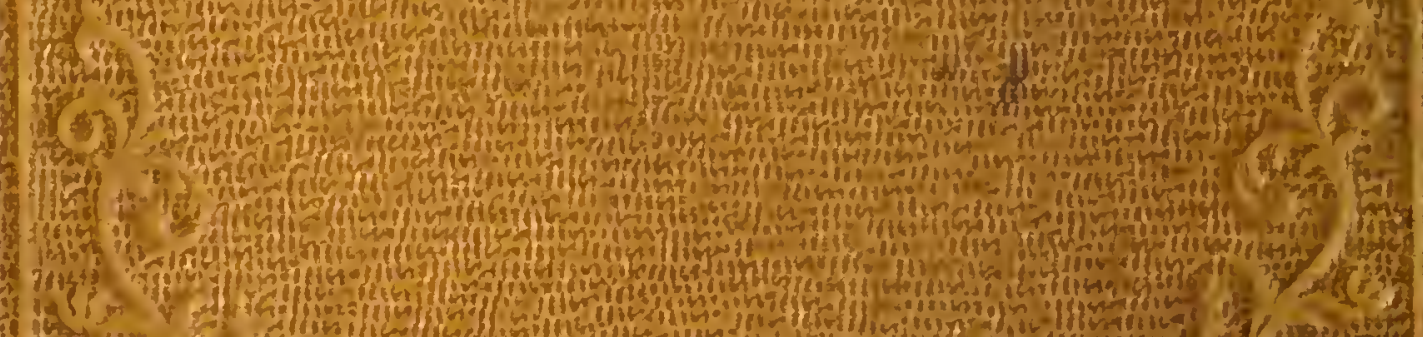

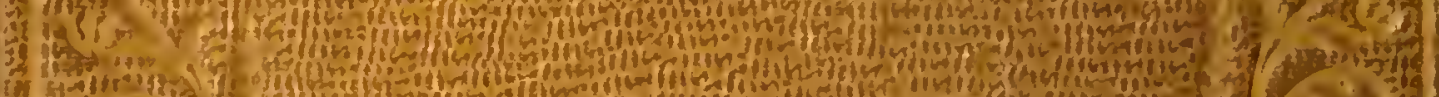

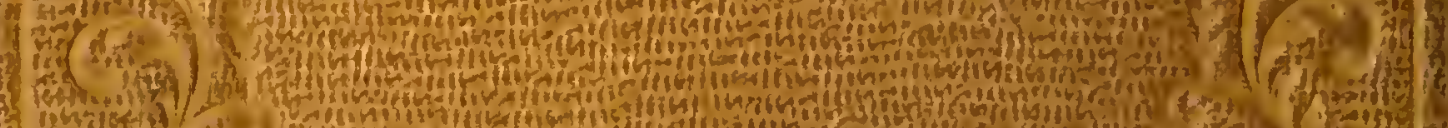
natstit? (1) inifes witiol,

th

? (2) 1

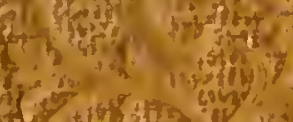
समी $(-4)$. ind

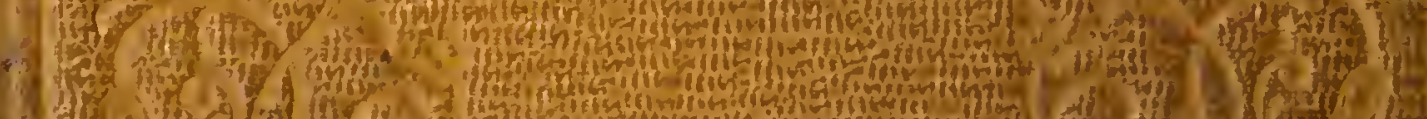

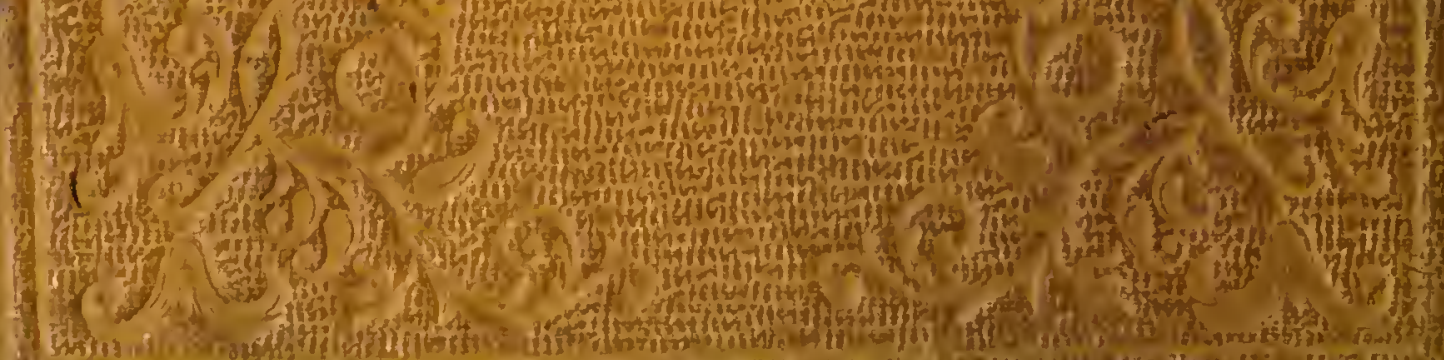

